AperTO - Archivio Istituzionale Open Access dell'Università di Torino

Molecular analysis and associated pathology of beak and feather disease virus isolated in Italy from young Congo African grey parrots (Psittacus erithacus) with an "atypical peracute form" of the disease.

This is the author's manuscript

Original Citation:

Availability:

This version is available http://hdl.handle.net/2318/149752

since 2016-11-30T01:17:20Z

Published version:

DOI:10.1080/03079457.2014.934660

Terms of use:

Open Access

Anyone can freely access the full text of works made available as "Open Access". Works made available under a Creative Commons license can be used according to the terms and conditions of said license. Use of all other works requires consent of the right holder (author or publisher) if not exempted from copyright protection by the applicable law. 


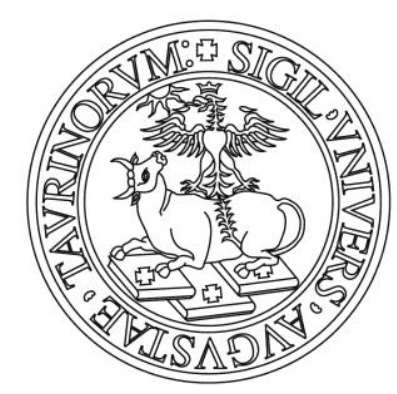

\section{UNIVERSITÀ DEGLI STUDI DI TORINO}

This is an author version of the contribution published on:

Avian Pathology, Volume 43, Issue 4, 2014, DOI:10.1080/03079457.2014.934660

The definitive version is available at:

http://dx.doi.org/10.1080/03079457.2014.934660

Questa è la versione dell'autore dell'opera su :

Avian Pathology, Volume 43, Issue 4, 2014, DOI:10.1080/03079457.2014.934660

La versione definitiva è disponibile alla URL:

http://dx.doi.org/10.1080/03079457.2014.934660 


\title{
Molecular analysis and associated pathology of beak and feather disease virus isolated in Italy from young Congo African grey parrots (Psittacus erithacus) with an "atypical peracute form" of the disease
}

\author{
Patrizia Robino ${ }^{1}$, Elena Grego ${ }^{1}$, Giacomo Rossi ${ }^{2}$, Elena Bert ${ }^{3}$, Clara Tramuta ${ }^{1}$, Maria \\ Cristina Stella ${ }^{1}$, Pierfrancesco Bertoni ${ }^{4}$, and Patrizia Nebbia ${ }^{1}$
}

${ }^{I}$ Department of Veterinary Sciences, University of Turin, Grugliasco, Turin, Italy, ${ }^{2}$ Department of Veterinary Sciences, University of Camerino, Matelica, Macerata, Italy, ${ }^{3}$ Veterinary Hospital Monviso, San Secondo di Pinerolo, Turin, Italy, and ${ }^{4}$ Veterinary Health Center, Fabbrico, Reggio Emilia, Italy

\begin{abstract}
This study is the first report on the genetic and pathogenic characterization of beak and feather disease virus (BFDV) occurring in Italy. Twenty BFDV strains isolated in Italy from juvenile Congo African grey parrots (Psittacus erithacus) were investigated. Seventeen strains showed an "atypical peracute form" (aPF) of the disease, and three a chronic form (CF). Usually, the peracute form affected neonatal or fledgling chicks, presenting with haemorrhage and/or multiorgan necrosis. The affected birds had been weaned, were independent as far as food and protection were concerned and apparently were without lesions. The gene coding for the putative coat protein was amplified in all isolates while the BFDV genome was sequenced completely in 10 samples, eight of them belonging to aPF affected birds and two from $\mathrm{CF}$ of the disease. All full genomes clustered into the J strain of BFDV, where two new subtypes were identified. Recombination analyses showed evidence of genetic exchanges in two BFDV genomes. In addition, a correlation between viral isolate and origin of the breeding material was shown, while an association between the genetic features of the virus and the clinical form was not observed. Histologically, apoptosis was detected frequently in aPF samples and sporadically in $\mathrm{CF}$ samples. Interestingly, BFDV antigens were detected in the nuclei and cytoplasm of such apoptotic cells. The data presented here support the hypothesis that, in the absence of a defined BFDV genetic variant accountable for a specific clinical form of psittacine beak and feather disease, differences in the apoptotic rate among aPF and CF are strictly host related.
\end{abstract}

Keywords: beak and feather disease virus, Psittacus erithacus, phylogenetic analysis, Italy

\section{Introduction}

Psittacine beak and feather disease (PBFD) is a cosmopolitan disease affecting numerous species of domestic and wild birds of the order Psittaciformes in the world. The disease is caused by a small virus roughly $2 \mathrm{~kb}$ in size characterized by a non-enveloped, icosahedral, circular, ambisense, non-segmented, single-stranded DNA. Beak and feather disease virus (BFDV) is a member of the genus Circovirus, family Circoviridae. These viruses are composed of up to seven open reading frames (ORF1 to ORF7), two of which, ORF1 and the ORF2, are well described, while the others are not always present and are less characterized (Ritchie et al., 1989; Bassami et al., 1998; Heath et al., 2004; Julian et al., 2013). ORF1 (rep gene) is present in the virion sense strand, encodes the viral replication-associated protein Rep (Bassami et al., 1998; Faurez et al., 2009) and shows highly conserved amino acid motifs (Mankertz et al., 1998; Heath et al., 2004). ORF2 (cp gene) translated in the complementary strand encodes the major structural capsid protein $(\mathrm{CP})$, responsible for the encapsidation of the virus and its entry into the cells as well as for the viral crossing of the nuclear envelope (Ritchie et al., 1989; Niagro et al., 1998; Heath et al., 2006). These two ORFs display different rates of evolution, with the Rep being relatively more conserved than the CP (Varsani et al., 2011; Julian et al., 2013). The intergenic region between the two major ORFs contains a replication hairpin loop structure (TAGTATTAC) that is characteristic and highly conserved in all BFDV circo viruses. These viruses have been described as ecologically stable and can be transmitted 
by both horizontal and vertical routes (Ritchie, 1995; Niagro et al., 1998; Rahaus et al., 2008). Usually, the clinical forms vary from species to species and depend on the age of the bird when infected (Gerlach, 2004). PBFD is a potentially fatal disease and can be present as a peracute, acute, or chronic form (CF) of infection; the latter is the most frequent form, known as the "classical form". Frequently, in birds up to 3 years of age, the disease begins with depression and lethargy followed by a chronic, progressive, bilateral and symmetrical feather dystrophy occasionally accompanied by beak deformity. Until now only peracute and acute forms have been described in nestling and fledgling parrots (Schoemaker et al., 2000; Doneley, 2003; Rahaus \& Wolff, 2003; Raue et al., 2004). Here, death may occur suddenly, without evidence of feather dystrophy (peracute form) or with mild evidence of feather dystrophy (acute form). In addition, BFDV-infected birds, especially those with chronic infection, typically display lymphoid depletion and immunosuppression that favour the appearance of opportunistic secondary infections (Ritchie et al., 1989; Todd, 2000), often leading to death. Currently, there is no cure or effective treatment for the disease caused by BFDV. Moreover, the production of a protective vaccine is hampered by the lack of success in culturing BFDV in vitro.

The international trade in exotic parrots, both through legal trade and illegal trafficking, has facilitated the spread of BFDV, such that BFDV can now be considered a global disease. It is likely that in Italy, as in Poland (Julian et al., 2013), there have been multiple introductions of BFDV over a long period of time. Consequently, captive infected birds kept in close proximity have favoured the recombination of different BFDV strains leading to the evolution of new viral subtypes. An epidemiological study carried out in Italy (Bert et al., 2005) showed that there was a high occurrence of infection in parrots imported from the "Old World" (South East Asia, Africa). In these birds the infection was mainly restricted to Cacatua and Congo African grey parrots (CAGPs), indicating a high susceptibility to BFDV in these two species. Over the years, several classifications have been proposed by different authors (Ritchie et al., 2003; de Kloet \& de Kloet, 2004; Heath et al., 2004; Varsani et al., 2011). Following the recent classification system proposed by Varsani et al. (2011), the predominant strain circulating in Europe is BFDV-J, a strain isolated mainly from Psittacus erithacus. Other strains circulating in these parrots in Europe are BFDV-I (Poland and Portugal), BFDV-J (Germany, Poland, Portugal, the UK) and BFDV-T (Poland), as reported by Varsani et al. (2011) and Julian etal. (2013).

The purpose of this study was to characterize the BFDV strains circulating amongst juvenile CAGPs that died of an "atypical peracute form" (aPF) of the disease, involving weaned parrots 4 to 6 months of age, and to document the associated histopathology. Finally, this study looked at the phylogenetic relationships of these strains in comparison with previously reported sequences.

\section{Materials and Methods}

Study design. Between April 2008 and November 2011, all 4-month-old to 6-month-old handreared, weaned and fully fledged CAGPs from well-managed breeding centres in Northern and Central Italy that died suddenly were submitted to our laboratory for investigation. Before death, some of the birds had displayed mild lethargy and anorexia. The occurrence of BFDV was confirmed by polymerase chain reaction (PCR), using the protocol described by Ypelaar et al. (1999). The presence of other pathogens, such as Chlamydia psittaci, Polyoma virus and herpesvirus (Pacheco's disease), which could present a similar clinical picture, were excluded by molecular analysis (PCR amplification). Prior to this investigation, parents of infected birds and other randomly selected parrots in each breeding centre had been tested. All centres were negative for BFDV with the exception of one, where we documented a $2 \%$ incidence of BFDV in asymptomatic birds.

Sample collection. This study was carried out on samples of various organs from 17 young CAGPs (4 to 6 months of age) that died suddenly with an aPF of BFDV Samples from three adult birds $(3,8$, and 11 years oldrespectively) that had died with typical signs of the CF of BFDV (such as abnormal feathers and beak lesions) were also included. The samples from birds with aPF originated from nine breeding centres: seven from one centre, three from another centre and one sample each from the remaining seven centres. The samples from the adult birds were provided by three private owners (Table 1).

Histology, immunohistochemistry and TUNEL evaluation. For 10 of the 20 CAGPs analysed in the study (eight showing an aPF and two a CF of the disease), a full necropsy was performed and target organs were sampled for histological, immunohistochemical and terminal 
deoxynucleotidyl transferase dUTP nick end-labelling (TUNEL) examination. The organs analysed were the liver, spleen, thymus, heart, lung, kidney, bursa of Fabricius and femoral bone marrow (BM). These samples were fixed in $10 \%$ neutral buffered formalin, paraffin embedded and serially sectioned at $3 \mu \mathrm{m}$.

Archived formalin-fixed, paraffin wax-embedded tissues from three CAGPs with no history of clinical diseases and negative for BFDV on PCR were retrieved from the University of Camerino Veterinary Pathology Unit archives. These samples had been obtained at postmortem from parrots that were presented for euthanasia following severe trauma and their ages ranged from 8 to 11 years. These samples were used as histological controls.

\section{Immunohistochemical tests}

For this purpose, rehydrated sections were treated for endogenous peroxidase neutralization with 3\% hydrogen peroxide for $5 \mathrm{~min}$ followed by rinsing for $5 \mathrm{~min}$ in distilled water. Antigen retrieval was achieved by incubating the slides in two antigen retrieval solutions - citrate buffer, pH 6.0 (for BFDV and interleukin [IL]-1 $\beta$ ); and $0.01 \mathrm{M}$ Tris-ethylenediamine tetraacetic acid buffer, $\mathrm{pH} 9.0$ (for caspase-1) - in a steamer according to the instructions of the manufacturer (Black \& Decker, Towson, MD, USA) for $20 \mathrm{~min}$. Non-specific immunoglobulin binding was blocked by incubating the slides for $10 \mathrm{~min}$ with a protein-blocking agent (Dako, Carpinteria, CA, USA). The slides were then incubated overnight in a moist chamber with the following primary antibodies: anti-BFDV hyper-immune serum (from an adult CAGP with CF of the disease, diagnosed by PCR, and highly reactive with intracellular inclusions of BFDV within affected tissues), rabbit anti-caspase-1 polyclonal antibody (Cell Signaling Technology, San Diego, CA, USA), and rabbit anti-chicken IL-1 $\beta$ (ACRIS Antibodies, San Diego, CA, USA). In brief, parrot serum, diluted 1:50 in phosphate-buffered saline+bovine serum albumin, anti-caspase-1 and anti IL-1 $\beta$ antibodies, both diluted 1:100 in the same buffer, were added and incubated overnight. Then, following three washing steps, biotinilated rabbit anti-chicken (Nordic Immunology, Tilburg, the Netherlands) or biotinilated goat anti-rabbit (Dako) antibodies were used.

Positive cells were detected with a streptavidin-immunoperoxidase staining procedure (Dako) using 3,3'-diaminobenzidine as the substrate (Vector, Burlingame, CA, USA). Tissue sections were counterstained with Mayer's haematoxylin. Immunohistochemical staining controls were slides in which primary antibodies were omitted. In the BM and lymphoid organ sections, the apoptotic index was highlighted through a TUNEL colorimet-ric staining (DeadEnd; Promega Madison, WI, USA) according to the manufacturer's instructions. For the evaluation of the apoptotic rate, 10 random fields in the tissue section were examined under a $40 \mathrm{x}$ dry objective. The number of BFDV, caspase-1 and TUNEL-positive cells was normalized to the number of cells per field and expressed as a percentage.

IL-1 $\beta$-positive cells were quantified in different lymphoid organs and BM, using a light microscope (Carl Zeiss Oberkochen, Germany), and a 40* objective. Ten sites were chosen and the mean value of the cellular staining with the anti-chicken IL-1 $\beta$ primary antibody was scored as follows: score $0,<25 \%$ of cells labelled; score 1,25 to $50 \%$ of cells labelled; score 2,50 to $75 \%$ of cells labelled; and score $3,>75 \%$ cells labelled. For all parameters, the cells on the margins of the tissue sections were not considered for evaluation.

Molecular analysis. The gene coding for the putative $c p$ was amplified by PCR in all isolates (17 from birds with aPF and three from birds with CF). Moreover, the BFDV genome was completely sequenced in 10 samples (eight from birds with aPF and two from birds with CF). The samples were identified using a progressive number on the basis of the year of isolation, the two-letter code identifying the country and the year of isolation (Table 1). Briefly, for DNA extraction, $25 \mathrm{mg}$ mixed organs stored in $100 \%$ ethanol were cut into small pieces and processed using the DNeasy Blood \& Tissue Kit (Qiagen, Milan, Italy), according to the manufacturer's instructions. Purified DNA was quantified and stored at $-80^{\circ} \mathrm{C}$ until use.

The full-length genomes of BFDV strains were amplified using several overlapping primer sets (Table 2). PCR amplifications were carried out in a total volume of $50 \mu$ l containing $1 \mathrm{x}$ storage buffer (Qiagen), $1.5 \mathrm{mM} \mathrm{MgCl} 2$ (3.5 $\mathrm{mM} \mathrm{MgCl}$ only for coat protein fragment amplification), $0.2 \mathrm{mM}$ of each dNTP, $0.5 \mathrm{pmol}$ of each primer, $2.5 \mathrm{U}$ Taq DNA polymerase (Qiagen) and 100 ng template DNA. PCR cycling conditions were as follows: 3 min denaturation at $94^{\circ} \mathrm{C}, 35$ cycles with steps of $30 \mathrm{sec}$ at $94^{\circ} \mathrm{C}, 30 \mathrm{sec}$ at 58 or $60^{\circ} \mathrm{C}$ and $1 \mathrm{~min}$ at $72^{\circ} \mathrm{C}$, followed by a final extension of $5 \mathrm{~min}$ at $72^{\circ} \mathrm{C}$. PCR products were examined for correct size by agarose $(2 \%)$ gel electrophoresis in 1x TAE buffer, purified by ExoSAP-IT Clean-Up (USB, Affymetrix, Cleveland, $\mathrm{OH}$, USA Inc.) and sequenced by Macrogen Services (Amsterdam, the Netherlands). 
Phylogenetic analysis. Sequences obtained from positive samples were aligned with known BFDV sequences available on the GenBank database using the ClustalW program (Thompson et al., 1997). More specifically, $20 \mathrm{cp}$ sequences obtained in this study were compared with 37 $c p$ sequences of strains isolated from CAGPs in other parts of the world and the full genome of the 10 strains was aligned with the complete genome available on the GenBank database of 23 strains from CAGPs (Table 1). Phylogenetic analysis on the data rep $(\mathrm{n}=10)$ and $c p(n=20)$ sequences was performed. The aligned sequences were imported into the PAUP* version 4.0b 10 program (Swofford, 2003). The model of molecular evolution was estimated using a hierarchical likelihood ratio test approach and the Akaike information criterion (Akaike, 1973) implemented in the ModelTest version 3.7 computer program (Posada \& Crandall, 1998; Posada, 2001). Bayesian methods implemented in the MrBayes version 3.1.1 program (Huelsenbeck \& Ronquist, 2001; Ronquist \& Huelsenbeck, 2003) were used to draw phylogenetic trees and assess statistical support for clades. In detail, a Markov chain Monte Carlo search for 1,000,000 generations using two runs with four chains (temperature $=0.05$ ) was performed, and results were represented as a 50\% majority rule consensus tree. The sequence identity comparisons were made by the Nei-Gojobori method (Nei \& Gojobori, 1986). Recombination amongst all complete genomes from this study and complete sequences available in GenBank was analysed using the Recombination Analysis Tool (Etherington et al., 2006). The potential recombination events were evaluated using the default program setting when phylogenetic evidence of recombination was observed.

Sequence accession numbers. The sequences were submitted to GenBank. The accession numbers of whole sequences of BFDV were KF723391 (1IT08), KF723386 (2IT09), KF723385 (3IT09), KF72389 (4IT09), KF723393 (5IT09), KF723384 (6IT09), KF723388 (7IT09), KF723387 (8IT10), KF723390 (9IT11) and KF723392 (10IT11). The accession numbers for the $c p$ sequence were KF723402 (11IT09), KF723401 (12IT09), KF723395 (13IT09), KF723403 (14IT09), KF723399 (15IT10), KF723394 (16IT10), KF723400 (17IT10), KF723398 (18IT11), KF723397 (19IT11) andKF723396 (20IT11). 
Table 1. Summary of information relating BFDV full genomes and putative coat protein genes from African grey parrots (Psittacus erithacus) determined in this study (A and B) and obtained by GenBank (C and D).

\begin{tabular}{|c|c|c|c|c|c|c|c|c|}
\hline \multirow{2}{*}{$\begin{array}{c}\text { A. } \\
\text { Strain }\end{array}$} & \multicolumn{4}{|c|}{ Full genomes determined in this study } & \multirow{2}{*}{$\begin{array}{l}\text { B. } \\
\text { in } \\
\text { Strain }\end{array}$} & \multicolumn{3}{|c|}{$\begin{array}{l}\text { Sequences of the coat protein gene determined } \\
\text { in this study }\end{array}$} \\
\hline & Country, Year & $\begin{array}{c}\text { Clinical } \\
\text { signs }\end{array}$ & $\begin{array}{c}\text { Accession } \\
\text { no. }\end{array}$ & subtype & & Country, Year & $\begin{array}{l}\text { Clinical } \\
\text { signs }\end{array}$ & $\begin{array}{c}\text { Accession } \\
\text { no. }\end{array}$ \\
\hline $1 \mathrm{IT08}$ & North Italy, 2008 & peracute & KF723391 & $\mathrm{J} 7$ & 11IT09 $^{a}$ & Central Italy, 2009 & peracute & KF723402 \\
\hline 2IT09 & Central Italy, 2009 & peracute & KF723386 & $\mathrm{J} 1$ & $12 I T 09^{a}$ & Central Italy, 2009 & peracute & KF723401 \\
\hline $3 I T 09^{a}$ & Central Italy, 2009 & peracute & KF723385 & $\mathrm{J} 1$ & 13IT09 $^{\mathrm{a}}$ & Central Italy, 2009 & peracute & KF723395 \\
\hline $4 I T 09^{a}$ & Central Italy, 2009 & peracute & KF723389 & $\mathrm{J} 1$ & $14 I T 09^{a}$ & Central Italy, 2009 & peracute & KF723403 \\
\hline 5IT09 & North Italy, 2009 & peracute & KF723393 & $\mathrm{J} 1$ & 15 IT10 & North Italy, 2010 & peracute & KF723399 \\
\hline 6IT09 & Central Italy, 2009 & peracute & KF723384 & $\mathrm{J} 1$ & $16 \mathrm{IT} 10$ & North Italy, 2010 & peracute & KF723394 \\
\hline 7IT09 & North Italy, 2009 & chronic & KF723388 & $\mathrm{J} 1$ & 17IT10 & Central Italy, 2010 & peracute & KF723400 \\
\hline $8 I T 10$ & Central Italy, 2010 & chronic & KF723387 & $\mathrm{J} 1$ & 18IT11 $^{b}$ & North Italy, 2011 & peracute & KF723398 \\
\hline 9IT11 & North Italy, 2011 & peracute & KF723390 & $\mathrm{J} 2$ & 19IT11 $^{b}$ & North Italy, 2011 & peracute & KF723397 \\
\hline 10IT11 & North Italy, 2011 & peracute & KF723392 & J6 & 20IT11 & North Italy, 2011 & chronic & KF723396 \\
\hline C. & \multicolumn{4}{|c|}{ Full genomes gene obtained by GenBank } & \multicolumn{4}{|c|}{$\begin{array}{l}\text { D. Sequences of the coat protein gene obtained by } \\
\text { GenBank }\end{array}$} \\
\hline PT05 & Portugal, 2005 & classical & EU810208 & I1 & 1GE & Germany & acute & AY518899 \\
\hline PT08 & Portugal, 2008 & aspecific & EU810207 & $\mathrm{J} 2$ & 2GE & Germany & acute & AY518920 \\
\hline PT08-2\&3 & Portugal, 2008 & classical & GQ120621 & $\mathrm{J} 1$ & 7GE & Germany & acute & AY518902 \\
\hline PT09 & Portugal, 2009 & aspecific & GQ329705 & $\mathrm{J} 1$ & 73GE & Germany & acute & AY518914 \\
\hline PT09-2 & Portugal, 2009 & aspecific & GU047347 & $\mathrm{J} 1$ & 74GE & Germany & acute & AY518915 \\
\hline PEG07 & Germany, 2004 & acute & AY521237 & $\mathrm{J} 3$ & IND & India & unknown & AY518906 \\
\hline PEU01 & U.K., 2004 & acute & AY521238 & $\mathrm{J} 1$ & JAP & Japan & unknown & AY518905 \\
\hline PEP01 & Portugal, 2004 & acute & AY521236 & $\mathrm{I} 4$ & POR & Portugal & acute & AY518901 \\
\hline AFG3-ZA & S. Africa, 2003 & unknown & AY450443 & $\mathrm{I} 3$ & 11POR & Portugal & acute & AY518912 \\
\hline AFG4-ZA & S. Africa, 2003 & unknown & AY450435 & $\mathrm{C} 2$ & 16POR & Portugal & acute & AY518910 \\
\hline ZA-80A & S. Africa, 2008 & unknown & HM748920 & $\mathrm{I} 3$ & PR & Puerto Rico & none & AY518926 \\
\hline ZA-55A & S. Africa, 2008 & unknown & HM748931 & M1 & JB1UK & United Kingdom & acute & AY518904 \\
\hline BFDV1 & Thailand, 2006 & unknown & GU015012 & $\mathrm{F} 1$ & US34 & USA & acute & AY518927 \\
\hline BFDV2 & Thailand, 2006 & unknown & GU015013 & $\mathrm{F} 1$ & US36 & USA & acute & AY518928 \\
\hline PL688 & Poland, 2008 & unknown & JX221037 & $\mathrm{J} 4$ & & & & \\
\hline PL785 & Poland, 2009 & unknown & JX221041 & J5 & & & & \\
\hline PL336 & Poland, 2007 & unknown & JX221018 & $\mathrm{T} 1$ & & & & \\
\hline PL376 & Poland, 2007 & unknown & $\mathrm{JX} 221020$ & $\mathrm{~T} 1$ & & & & \\
\hline PL399 & Poland, 2007 & unknown & JX221022 & $\mathrm{T} 1$ & & & & \\
\hline PL410 & Poland, 2007 & unknown & JX221023 & $\mathrm{T} 1$ & & & & \\
\hline PL573 & Poland, 2008 & unknown & JX221032 & $\mathrm{J} 1$ & & & & \\
\hline PL711 & Poland, 2008 & unknown & JX221038 & I4 & & & & \\
\hline PL717 & Poland, 2008 & unknown & JX221039 & I4 & & & & \\
\hline
\end{tabular}

${ }^{\mathrm{a}}$ and ${ }^{\mathrm{b}}$ indicate strains obtained from birds were aviary mates, respectively. 
Table 2. Nucleotide sequence, location (nt) of the primers, predicted sized of the amplified products, and annealing temperature of the oligonucleotide primers designed to amplify the fulllength genomes of PBFDV.

\begin{tabular}{|c|c|c|c|c|c|c|}
\hline $\begin{array}{l}\text { Sets of } \\
\text { primers }\end{array}$ & Primers & Sequences (5'-3') & $\begin{array}{l}\text { Location }^{\mathrm{a}} \\
\text { (nt) }\end{array}$ & $\begin{array}{l}\text { Product size } \\
\text { (bp) }\end{array}$ & $\begin{array}{l}\text { Annealing } \\
\left({ }^{\circ} \mathrm{C}\right)\end{array}$ & Reference \\
\hline \multirow{2}{*}{$\mathbf{A}$} & $1 \mathrm{~F}$ & CGAAGACTACCGRATTAAGTTA & $1691-1670$ & \multirow{2}{*}{579} & \multirow{2}{*}{58} & \multirow{2}{*}{ This study } \\
\hline & $2 \mathrm{R}$ & AACGATGGCATAGTAGAATTCG & $250-229$ & & & \\
\hline \multirow{2}{*}{ B } & $3 \mathrm{~F}$ & ATGCCGTCCAAGGAGGGCT & $131-149$ & \multirow{2}{*}{767} & \multirow{2}{*}{58} & \multirow{2}{*}{ This study } \\
\hline & $4 \mathrm{R}$ & GTCACAGTCCTCCTTGTACCA & $898-878$ & & & \\
\hline \multirow{2}{*}{$\mathbf{C}$} & $5 \mathrm{~F}$ & CCTTATTGCGAGATGCTCCG & $758-777$ & \multirow{2}{*}{638} & \multirow{2}{*}{58} & \multirow{2}{*}{ This study } \\
\hline & $6 \mathrm{R}$ & TGGATCCCACTACAAGGAGGA & $1376-1396$ & & & \\
\hline \multirow{2}{*}{$\mathbf{D}$} & $7 \mathrm{~F}$ & ACCTCTAACTGCGCATGC & $1975-1958$ & \multirow{2}{*}{801} & \multirow{2}{*}{60} & \multirow{2}{*}{ This study } \\
\hline & $8 \mathrm{R}$ & CACGGTAGCGCCGAAGG & $1174-1190$ & & & \\
\hline
\end{tabular}

${ }^{\mathrm{a}}$ The position of the primers is referred to the sequence PEU01 (Acc. AY521238)

\section{Results}

Necropsy. In the eight juvenile parrots that died with the aPF of BFDV, gross lesions were absent. The parrots displayed good muscle and plumage development; however, it was of interest that all of these birds were severely anaemic (based on laboratory tests performed in vivo by various practitioners). In comparison, the two adults with the CF of the illness showed mainly feather abnormalities such as shortness, clubbing and anomalous curling. There was also moderate atrophy of the pectoral muscles, and the livers were enlarged and mottled with scattered foci of necrosis, as were the spleens. Botryoid inclusion bodies were seen in macrophages of some of the feather follicles and in some spleen and intestinal macrophages. No abnormalities were detected in the BM of the CF group.

Histology. The histological picture from the aPF affected birds was similar, consisting of lymphoid depletion in the spleen, thymus and bursal follicles. There were also foci of hepatic necrosis and severe BM atrophy. The lymphoid tissue was markedly atrophic with large numbers of cells undergoing apoptosis together with scattered areas of necrosis. In some cases, the only histologic lesion in birds affected with the aPF of the disease was severe necrosis of bursal, thymic, and BM elements. In the lymphoid organs, and especially in the BM, apart from the apoptotic lymphocytes, many infiltrating macrophages were also observed (Figure $1 \mathrm{a}, \mathrm{b}$ ). In these birds, since viral inclusions were not visible in any of the damaged tissues (Figure $1 \mathrm{c}, \mathrm{d})$, even if the signs were suggestive of a viral infection, BFDV was not the prime suspect. The histological picture in the two parrots affected by the CF of the disease was characterized by similar lesions in the beak and feathers and included necrosis and hyperplasia of the epithelial cells in the basal and intermediate epithelial layers. The feather pulp was infiltrated mainly by heterophils, plasma cells and macrophages with lesser numbers of lymphocytes. In this group of birds, basophilic nuclear and cytoplasmic inclusions were detected in epithelial cells, whereas inclusions were frequently found in macrophages in the epidermis, feather pulp cavity and lymphoid tissue cytoplasmic (data not shown).

Immunohistochemical and TUNEL evaluations. Higher numbers of apoptotic cells were detected in the spleen, thymus, bursa and BM of aPF affected compared with $\mathrm{CF}$ affected CAGPs, by concurrent positive TUNEL assay and immunostaining for activated caspase-1 (Figure 1e,f,g,h). A large number of the caspase-1-positive cells exhibited a concomitant staining with BFDV antiserum (Figure 1c,d,e,f). Apoptotic cells were frequently detected in the enlarged germinal centres of spleens and bursa in the aPF and only sporadically in the same organs of the CF. No BFDV-positive cells and only low levels of caspase-1-positive cells were detected in the tissues from the euthanized parrots, retained as control (data not shown). The apoptotic index of the different organs in the three groups of birds (aPF, CF and euthanized) is reported in Table 3, in association with the mean percentage value of BFDV-positive cells.

Apoptotic cells, identified by activated caspase-1 and TUNEL corresponded to cells with microscopic changes typical of apoptosis in haematoxylin and eosin stained sections. The cytoplasm and less frequently the nuclei of many apoptotic cells in the bursal and spleen 
germinal centres were positive for BFDV antigens while BFDV was occasionally identified in normal and apoptotic BM cells of CF affected CAGPs (Figure 1c).

Molecular analysis. The complete genome sequences of 10 BFDV strains as well as nucleotide sequences of the other 10 putative $c p$ genes were determined and analysed. The length of the full genomes ranged from 1997 to 2001 nucleotides with pairwise identities of between $93.6 \%$ and $99.9 \%$. The nucleotide identity among the $20 \mathrm{cp}$ sequences and the $10 \mathrm{rep}$ sequences varied respectively from $88.2 \%$ to $100 \%$ and from $95.5 \%$ to $100 \%$. The pairwise amino acid identity for $c p$ and rep protein was $>88.5 \%$ for $c p$ and $>98.8 \%$ for $r e p$.

The relevant genomic features of the full-length Italian strains are reported in Table 4. Briefly, all genomes contained the distinguishing nonanucleotide circovirus origin of replication (TAGTATTAC) located within a stem loop structure, the octamer sequences that most probably act as a binding site for BFDV Rep protein, the TATA boxes and the polyadenylation signals. The putative ORFs varied from four to six, instead of the seven ORFs described by Bassami et al. (1998). All strains contained the two major ORFs: ORF1, which codes for the rep gene, was 870 nucleotides in length, had a canonical ATG sequence as start codon and TAA or TGA as stop codon; and ORF2, which codes for $c p$ gene, was 750 nucleotides in length. The differences in the length of this gene in comparison with the data already published in the literature depend on the start codon that is chosen, since a canonical starting site is not evident (Bassami et al., 1998; de Kloet \& de Kloet, 2004; Henriques et al., 2010). Within all of these genomes we identified three conserved amino acid motifs (FTLNN, GTPHLQGY and YCSK), a P-loop for dNTP binding (GPPGCGKS, amino acids 165 to 172) and three additional conserved motifs (WWDGY, amino acids 190 to 194; DDFYGWLP, amino acids 203 to 210; DRYP, amino acids 219 to 222) within the rep gene (Henriques et al., 2010), and the nuclear localization domain (RRRYARPXYRR RHIRRYRLRRRRHFRRRRFXTNRIYTLRxKRQ) on the N-terminus of the CP (Heath et al., 2006).

Within the full genome of all Italian strains, ORF3, ORF4, ORF5 and ORF7 displayed a high degree of homology when compared with the corresponding sequences reported by Bassami et al. (1998) and Henriques et al. (2010). ORF3 and ORF5 were detected in all isolates. ORF4 and ORF7, truncated or incomplete, were considered absent only in three strains (1IT08, 9IT11, 10IT11). ORF6 was absent in all strains analysed. For details, see Table 5. 

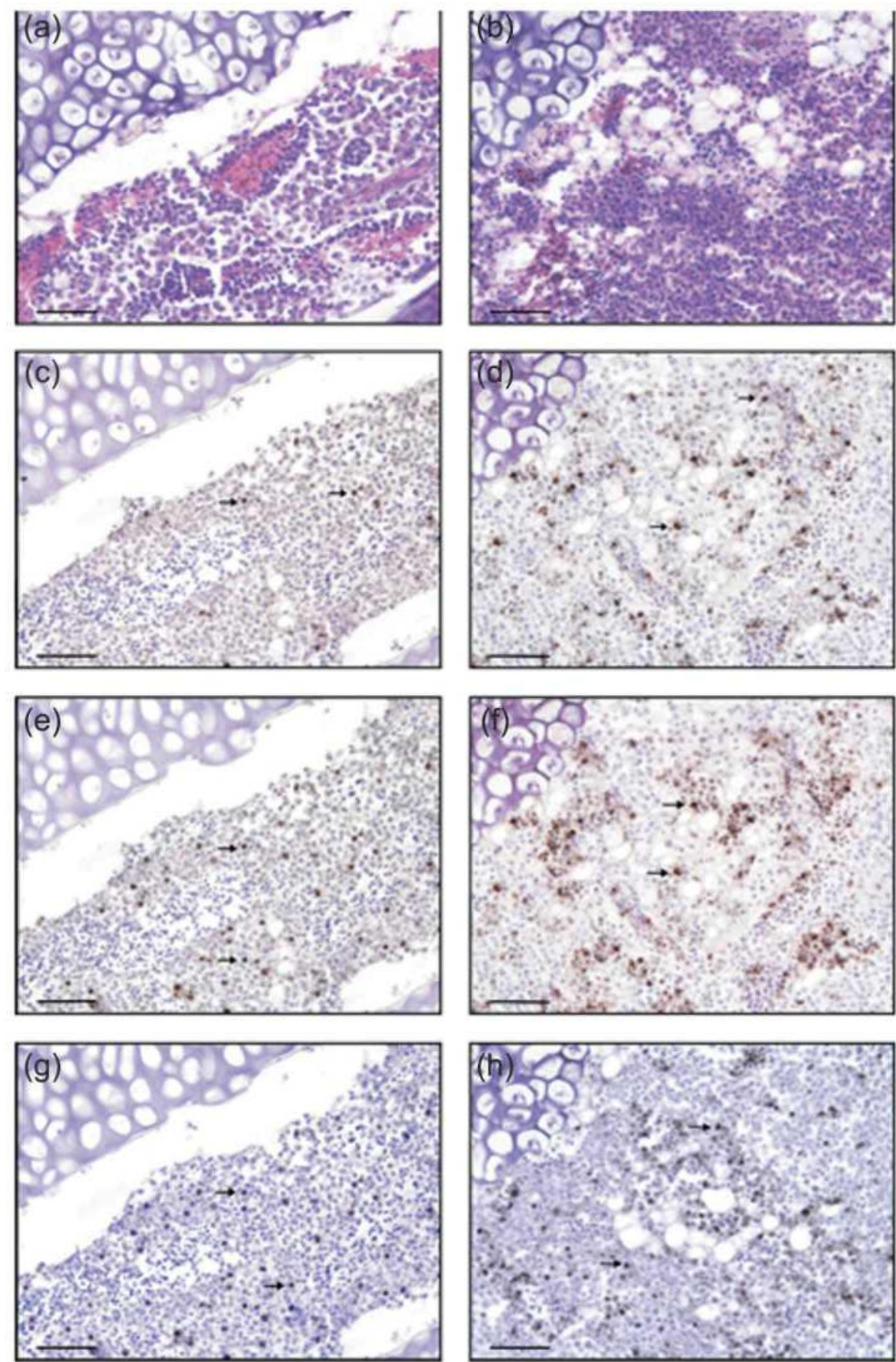

Figure 1. Bone marrow (BM) histological sections: aPF and $C F$ of PBFD. CF bone marrow (1a), bone marrow in aPF is partially replaced by fat tissue (atrophy) (1b). In the same sections, immunohistochemical staining (BFDV antigen): a lower number of BFDV-positive myeloid cells are present in CF (1c) compared with aPF (arrows) (1d). Numerous BFDVpositive cells are also positive for caspase-1 (arrows) (1e, If). A similar pattern of nuclear positivity is observed in caspase-1 and TUNEL stained myeloid cells $(1 \mathrm{~g}$, 1h), with a higher number of TUNEL-positive cells being present in the aPF, particularly concentrated near the areas of adipose-metaplasia of the tissue (1h). Scale bar: $250 \mu \mathrm{m}$. 
Table 3. Immunohistochemical and TUNEL results on 10 African grey parrots (AGPs) necropsied in this study. Archived formalin-fixed, paraffin wax-embedded tissues from 3 AGPs deceased for accidental causes, negative for BFDV, were used as control.

\begin{tabular}{|c|c|c|c|c|c|}
\hline \multirow{2}{*}{ Organ } & Group & caspase-1 & IL-1 $\boldsymbol{\beta}$ & TUNEL & BFDV \\
\hline \multirow{3}{*}{ Thymus } & $\mathbf{a P F}^{\mathbf{a}}$ & $42.3 \%$ & 11.25 & $38.2 \%$ & $13 \%$ \\
\cline { 2 - 6 } & $\mathbf{C F}^{\mathbf{b}}$ & $27.5 \%$ & 5 & $17 \%$ & $8 \%$ \\
\cline { 2 - 6 } & $\mathbf{E P}^{\mathbf{c}}$ & $2 \%$ & 1.5 & $0.5 \%$ & $0 \%$ \\
\hline \multirow{3}{*}{ Bursa } & $\mathbf{a P F}$ & $52.18 \%$ & 11.5 & $42.8 \%$ & $28 \%$ \\
\cline { 2 - 6 } & $\mathbf{C F}$ & $37 \%$ & 3 & $35.55 \%$ & $15 \%$ \\
\cline { 2 - 6 } & $\mathbf{E P}$ & $7 \%$ & 0.5 & $4 \%$ & $0 \%$ \\
\hline \multirow{3}{*}{ Spleen } & $\mathbf{a P F}$ & $61 \%$ & 10.75 & $51.2 \%$ & $31 \%$ \\
\cline { 2 - 6 } & $\mathbf{C F}$ & $44.5 \%$ & 8.5 & $48.5 \%$ & $27 \%$ \\
\cline { 2 - 6 } & $\mathbf{E P}$ & $13.5 \%$ & 1.5 & $11.5 \%$ & $0 \%$ \\
\hline \multirow{3}{*}{ Bone marrow } & $\mathbf{a P F}$ & $55.8 \%$ & 12.25 & $46.3 \%$ & $35.7 \%$ \\
\cline { 2 - 6 } & $\mathbf{C F}$ & $4.5 \%$ & 2.5 & $3 \%$ & $2.5 \%$ \\
\cline { 2 - 6 } & $\mathbf{E P}$ & $2 \%$ & 0 & $1.5 \%$ & $0 \%$ \\
\hline
\end{tabular}

${ }^{\mathrm{a}} \mathrm{aPF}$ (atypical peracute form: 8 parrots); ${ }^{\mathrm{b}} \mathrm{CF}$ (chronic form: 2 parrots); ${ }^{\mathrm{c}} \mathrm{EP}$ (euthanized parrots: 3 parrots).

The number of BFDV, caspase-1, and T.U.N.E.L.-positive cells is normalized to the number of cells per field and express as a percentage of these values.

The total score of IL-1 $\beta$ positive cells results from the mean value obtained from the scores deriving from each organs examined per all the bird of each cathegory (aPF, CF, EP).

Phylogenetic analysis. The phylogenetic analysis of the 10 complete nucleotide sequences of BFDV strains isolated in Italy from CAGPs clustered in subtypes of the BFDV-J strain. Moreover, according to the subdivision into subgroups proposed by Varsani et al. (2011), seven samples were included into subgroups J1 (2-3-4-5-6-7IT09, 8IT10) and one into $\mathbf{J}_{2}$ (9IT11). Furthermore, in agreement with these criteria (pairwise identity and phylogenetic distribution), we proposed two new subtypes: $\mathrm{J}_{6}$ (10IT11) and $\mathrm{J}_{7}$ (1IT08) (Figure 2). Notably, the pairwise sequence identity between subtypes ranged from 98 to $100 \%$.

The full-length genomes of Italian viruses clustered into two close major clades belonging to the BFDV-J strain, together with other isolates from Germany (PEG07), Poland (PL573; PL688; PL785), Portugal (PT08; PT08-2\&3, PT09, PT09-2) and the UK (PEU01), confirming that BFDV-J is the main strain infecting CAGPs in Europe, as described previously (Varsani et al., 2011; Julian et al., 2013). Two strains from Portugal and some strains from Poland (I and T subtypes) clustered with strains from CAGPs from Thailand and South Africa, belonging to other subtypes (Figure 2).

The phylogenetic analysis of the deduced amino acid coat protein (Figure 3) showed that 1 IT08 together with the partial coat sequence 20IT11 clustered in the subtype M1. Thus, we decided to evaluate possible recombination events. This analysis showed a recombination event in the $c p$ gene of 1IT08 (complete sequence) and in the $c p$ gene of 20IT11. In detail, the 1IT08 displayed a recombination between $\mathrm{M}$ and $\mathrm{F}$ subtypes, while $20 \mathrm{IT} 11$ a recombination with $\mathrm{M}$ and I subtypes. The pairwise identity of the complete 1IT08 genome in comparison with the other $\mathrm{J}$ strain was $93.6 \%$, slightly under the threshold of $94 \%$ that was considered by Varsani et al. (2011) as the BFDV strain demarcation. Considering the pairwise identity, the phylo-genetic distribution and the relevant genomic features of BFDV strains, we decided to classify the 1 IT08 as a subtype $\mathrm{J}_{7}$.

In other samples, the phylogenetic analysis of CP (Figure 3) and REP (data not shown) proteins reflects the division into two major subgroups, namely $\mathrm{J} 1$ and $\mathrm{J} 2$, as suggested by the analysis of the full nucleotide sequence. We could not observe significant differences comparing sequences isolated from birds affected by aPF and sequences of viruses isolated in parrots displaying $\mathrm{CF}$ of the illness, either within our isolates or including sequences already present in the literature. Moreover, we did not observe any correlation between the phylogenetic distribution and regional origin of the samples, since strains from northern Italy (5IT09, 7IT09, 9IT11) grouped together with others from central Italy (2-3-4-6IT09, 8IT10). As expected, the sequences from the same breeding centre clustered most closely among them ( $>99.4 \%$ coat nucleotide pairwise identity).

\section{Discussion}

To gather more information concerning the virus causing PBFD in Italy, we have characterized the strains originating from outbreaks of aPF beak and feather disease in young CAGPs that were fledged and weaned. The aPFs described in this study were characterized by sudden death, 
or general good bodily condition without any classical feather or beak alterations but with severe leukopenia and anaemia. This was associated with a high incidence of apoptosis in the lymphoid organs and especially in the BM. In addition, apoptotic caspase-1-positive and TUNEL-positive cells also showed concurrent positivity to BFDV staining without the typical botryoid and basophilic inclusion bodies. This particular clinical and post-mortem presentation of the disease is very similar to those reported by Schoemaker et al. (2000) in young CAGPs.

We analysed both nucleotide and amino acid sequences of the $c p$ genes from 20 birds, and in 10 of these (eight from young birds with aPF and two from adults with $\mathrm{CF}$ of the disease) necropsy was performed and the complete genome characterized. The main genomic features of these strains were compared with BFDV sequences available on the GenBank database. BFDV from CAGPs isolated in Italy clustered in subtypes of the J-strain: this finding is in agreement with the literature that ascribes the $\mathrm{J}$ strains as characteristic of European countries (Varsani et al., 2011; Julian et al., 2013). Moreover, according to the classification criteria proposed by Varsani et al. (2011) we suggested two new subtypes: $\mathbf{J}_{6}$ and $\mathbf{J}_{7}$. Of interest, two birds showed that novel recombination events had taken place among BFDV strains belonging to the subtypes M, I and F, these strains being commonly present in Africa and Indonesia, which are the two major areas from which parrots imported into Italy originate (Bert et al., 2005). We observed that the viral sequences of strains that produce the peracute illness clustered closely with the strains responsible for the chronic disease, thus suggesting the absence of a specific BFDV genetic variant accountable for a specific form of PBFD, as formerly hypothesized (Ypelaar et al., 1999; Bassami et al., 2001; Heath et al., 2004; Raue et al., 2004; Hughes \& Piontkivska, 2008). On the basis of this observation, we have hypothesized that the clinical and pathological differences between aPF and CF of the disease could be strictly related to the age and host immune system status, rather than genomic differences between viral strains. The parrots with the aPF in this study were severely anaemic. Since much evidence supports the view that the main sites of virus replication are the haemocytoblasts in the BM and the precursor lymphocytes in the lymphoid organs (Adair, 2000), this anaemia could result from the direct effect of the virus on the erythroblast precursor cells in the BM. Chicken anaemia virus, a member of the Circoviridae family, affects T-cell precursors during the development of the thymic cortex, leading to depletion of helper (CD4) and cytotoxic (CD8) Tcell populations in chicks (Randall et al., 1984; Goryo et al., 1987; Otaki et al., 1988; Adair et al., 1991; Bounous et al., 1995; Adair, 1996, 2000; Adair \& McNulty, 1997). Since we observed extensive lymphoid depletion, it would appear that BFDV, similarly to chicken anaemia virus, has an immunosuppressive effect in young parrots. Here we show that BFDV induces different apoptosis phenomena in juvenile birds compared with adults. Until now, the mechanism of BFDV-induced apoptosis was unknown. A possible mechanism could be the direct effect of a BFDV-encoded protein on virus infected and uninfected bystander cells, as in the apoptin encoded by chicken anaemia virus, a $14 \mathrm{kDa}$ proline-rich protein that causes $\mathrm{p} 53$ independent but caspase-3 -dependent apoptosis in thymic lymphoblasts, intra-sinusoidal and extra-sinusoidal haemocytoblasts, and reticular cells (Zhuang et al., 1995a, b; Danen-van Oorschot et al., 1999, 2000; Pietersen \& Noteborn, 2000). Even if we cannot exclude nonspecific phagocytosis, the frequent co-localization of viral antigens and apoptotic events we observed is suggestive of a direct association between BFDV infection and apoptosis. The fact that porcine circovirus 2 (a close relative of BFDV) activates caspase- 8 and caspase- 3 pathways, leading to apoptosis in the lymphoid organs (Liu et al., 2005), lends support to this hypothesis. The severity of apoptosis in porcine circovirus 2 is also age dependent, with the most severe occurring in the youngest pigs. In contrast to the other caspases, caspase- 1 is generally believed to be pro-inflammatory (Ghayur et al., 1997; Thornberry \& Lazebnik, 1998). Caspase-1 (also referred to as IL-1 $\beta$ converting enzyme) regulates lipopoly-saccharide-induced interferon- $\gamma$ production and in macrophages leads to cleavage of the precursor IL-1 $\beta$ into active IL- 1 that subsequently initiates an intense host inflammatory response. In this study, the strong upregulation of caspase- 1 in young parrots clinically affected by aPF, corresponded with an upregulation of IL-1 $\beta$. This would account for the inflammation characterized by the infiltration of heterophils, plasma cells and macrophages that was observed. As described in porcine circovirus 2 infected pigs (Liu et al., 2005), ORF3 of BFDV may play a major role in the agerelated levels of induction of apoptosis and inflammation through activation of the caspase-1/IL$1 \beta$ pathway, by the synthesis of a specific apoptin-like protein. As the tropism of BFDV for rapidly dividing cells is known (Todd et al., 2001), we can speculate that young parrots, with their faster growth rate, are more sensitive to BFDV infection. This is in agreement with the higher percentage of BFDV-positive cells that we observed in aPF affected parrots when compared with CF-positive birds. Consequently, the clinical and pathological differences observed in the $\mathrm{aPF}$ and the $\mathrm{CF}$ of the disease could ultimately be due to the different 
activation of caspase-1, IL-1 and apoptotic pathways due to different amounts of BFDV present.

In conclusion, the data presented support the hypothesis that, in the absence of a defined BFDV genetic variant accountable for a specific clinical form of PBFD, differences between aPF and $\mathrm{CF}$ are strictly host related.

Table 4. Genomic features of the PBFDV strains isolated in Italy (reference sequence: PEU01, GenBank accession AY521238).

\begin{tabular}{|c|c|c|c|c|c|c|}
\hline Genomic features & & 3-4-5-7IT09; 8IT10 & 2IT09; 6IT09 & 1 IT08 & 9IT11 & 10IT11 \\
\hline & & \multicolumn{5}{|c|}{ location (nt) } \\
\hline Intergenic region & $76 \mathrm{nt}$ & $\begin{array}{l}1986-2000 \\
\text { and } 1-61\end{array}$ & $\begin{array}{l}1987-2001 \\
\text { and } 1-61\end{array}$ & $\begin{array}{l}1984-1998 \\
\text { and } 1-61\end{array}$ & $\begin{array}{l}1985-1999 \\
\text { and } 1-61\end{array}$ & $\begin{array}{l}(75 \mathrm{nt}) 1983-1997 \\
\text { and } 1-60\end{array}$ \\
\hline \multirow{4}{*}{ Stem structure } & CCGCCGCC & $3-10$ & $3-10$ & - & - & - \\
\hline & GGCGGCGG & 1985-1992 & 1986-1993 & - & - & - \\
\hline & CCGCCGCCT & - & - & $3-11$ & $3-11$ & $3-11$ \\
\hline & AGGCGGCGG & - & - & $1982-1990$ & 1983-1991 & 1981-1989 \\
\hline \multirow{4}{*}{$\begin{array}{l}\text { Octamer repeats } \\
\text { and [internal hexamers] }\end{array}$} & \multirow{2}{*}{$\mathrm{G}[\mathrm{GGGCAC}] \mathrm{C}$} & $12-19$ & $12-19$ & $12-19$ & $12-19$ & $12-19$ \\
\hline & & $20-27$ & $20-27$ & $20-27$ & $20-27$ & $20-27$ \\
\hline & \multirow{2}{*}{ G[GTGCCC $] \mathrm{C}$} & $43-50$ & $43-50$ & - & - & $43-50$ \\
\hline & & 1974-1981 & 1975-1982 & 1972-1979 & 1973-1980 & 1971-1978 \\
\hline Only hexamer & GTGCCC & - & - & $52-57$ & $52-57$ & $51-56$ \\
\hline \multirow{4}{*}{ TATA boxes } & \multirow{3}{*}{ TATA } & $86-89$ & $86-89$ & - & - & - \\
\hline & & $938-941$ & $938-941$ & - & - & 934-937 \\
\hline & & $1749-1752^{\mathrm{a}}$ & - & $1747-1750$ & $1748-1751$ & 1746-1749 \\
\hline & TATAAA & $680-685$ & $680-685$ & $677-682$ & $677-682$ & $676-681$ \\
\hline \multirow{4}{*}{$\begin{array}{l}\text { Polyadenylation } \\
\text { signals }\end{array}$} & \multirow{4}{*}{ AATAAA } & 1197-1202 & $1198-1203$ & $1195-1200$ & $1196-1201$ & 1194-1199 \\
\hline & & - & - & - & - & $1503-1508$ \\
\hline & & $1237-1232$ & $1238-1233$ & $1235-1230$ & $1236-1231$ & $1234-1229$ \\
\hline & & $1461-1456$ & $1462-1457$ & & - & - \\
\hline
\end{tabular}

${ }^{\mathrm{a}}$ only 5IT09 
Table 5. List and properties of the ORFs detected in the PBFDV strains isolated in Italy (reference sequence: PEU01, GenBank accession AY521238).

\begin{tabular}{|c|c|c|c|c|c|c|c|c|c|}
\hline Strains & & & ORF1 & ORF 2 & ORF 3 & ORF 4 & ORF 5 & ORF 6 & ORF 7 \\
\hline \multirow{3}{*}{ 2IT09 } & Location & $\mathrm{nt}$ & $131-1000$ & 1986-1237 & $559-62$ & & $543-1013$ & & 1301-1017 \\
\hline & Gene length & nt & 870 & 750 & 498 & $\begin{array}{c}\text { Not } \\
\text { detected }\end{array}$ & 471 & $\begin{array}{c}\text { Not } \\
\text { detected }\end{array}$ & 285 \\
\hline & $\begin{array}{l}\text { Protein } \\
\text { length }\end{array}$ & $\begin{array}{c}\mathrm{aa} \\
(\mathrm{kDa})\end{array}$ & $289(33.5)$ & $249(29.3)$ & $165(18.3)$ & & $156(17)$ & & 94 (9.7) \\
\hline \multirow{3}{*}{ 3IT09 } & Location & $\mathrm{nt}$ & $131-1000$ & $1985-1236$ & $559-62$ & $1050-1388$ & $543-1013$ & & $1300-1034$ \\
\hline & Gene length & nt & 870 & 750 & 498 & 339 & 471 & $\begin{array}{c}\text { Not } \\
\text { detected }\end{array}$ & 267 \\
\hline & length & $(\mathrm{kDa})$ & $289(33.5)$ & $249(29.3)$ & $165(18.3)$ & $112(11.9)$ & $156(17)$ & & $88(9.0)$ \\
\hline \multirow{3}{*}{ 4IT09 } & Location & nt & $131-1000$ & $1985-1236$ & $559-62$ & $1050-1388$ & $543-1013$ & & $1300-1034$ \\
\hline & $\begin{array}{l}\text { Gene length } \\
\text { Protein }\end{array}$ & $\begin{array}{l}\text { nt } \\
\text { aa }\end{array}$ & 870 & 750 & 498 & 339 & 471 & $\begin{array}{c}\text { Not } \\
\text { detected }\end{array}$ & 267 \\
\hline & length & $(\mathrm{kDa})$ & $289(33.5)$ & 249 (29.3) & $165(18.3)$ & $112(11.9)$ & $156(17)$ & & $88(9.0)$ \\
\hline \multirow{3}{*}{ 5IT09 } & Location & nt & $131-1000$ & $1985-1236$ & $559-62$ & $1050-1388$ & 543-1013 & & $1300-1034$ \\
\hline & $\begin{array}{l}\text { Gene length } \\
\text { Protein }\end{array}$ & $\begin{array}{l}\text { nt } \\
\text { aa }\end{array}$ & 870 & 750 & 498 & 339 & 471 & $\begin{array}{c}\text { Not } \\
\text { detected }\end{array}$ & 267 \\
\hline & length & $(\mathrm{kDa})$ & $289(33.5)$ & $249(29.3)$ & $165(18.3)$ & $112(11.9)$ & $156(17)$ & & $88(9.0)$ \\
\hline \multirow{3}{*}{ 6IT09 } & Location & $\mathrm{nt}$ & $131-1000$ & 1986-1237 & $559-62$ & & 543-1013 & & $1301-1017$ \\
\hline & $\begin{array}{l}\text { Gene length } \\
\text { Protein }\end{array}$ & $\begin{array}{l}\text { nt } \\
\text { aa }\end{array}$ & 870 & 750 & 498 & $\begin{array}{c}\text { Not } \\
\text { detected }\end{array}$ & 471 & $\begin{array}{c}\text { Not } \\
\text { detected }\end{array}$ & 285 \\
\hline & length & $(\mathrm{kDa})$ & $289(33.5)$ & 249 (29.3) & $165(18.3)$ & & $156(17)$ & & $94(9.7)$ \\
\hline \multirow{3}{*}{ 7IT09 } & Location & $\mathrm{nt}$ & $131-1000$ & $1985-1236$ & $559-62$ & $1050-1388$ & $543-1013$ & & $1300-1034$ \\
\hline & $\begin{array}{l}\text { Gene length } \\
\text { Protein }\end{array}$ & $\begin{array}{l}\mathrm{nt} \\
\mathrm{aa}\end{array}$ & 870 & 750 & 498 & 339 & 471 & $\begin{array}{c}\text { Not } \\
\text { detected }\end{array}$ & 267 \\
\hline & length & $(\mathrm{kDa})$ & $289(33.5)$ & $249(29.3)$ & $165(18.3)$ & $112(11.9)$ & $156(17)$ & & $88(9.0)$ \\
\hline \multirow{3}{*}{ 8IT10 } & Location & nt & $131-1000$ & $1985-1236$ & $559-62$ & $1050-1388$ & & & $1300-1034$ \\
\hline & $\begin{array}{l}\text { Gene length } \\
\text { Protein }\end{array}$ & $\begin{array}{l}\text { nt } \\
\text { aa }\end{array}$ & 870 & 750 & 498 & 339 & $\begin{array}{c}\text { Not } \\
\text { detected }\end{array}$ & $\begin{array}{c}\text { Not } \\
\text { detected }\end{array}$ & 267 \\
\hline & length & $(\mathrm{kDa})$ & $289(33.5)$ & 249 (29.3) & $165(18.3)$ & $112(11.9)$ & & & $88(9.0)$ \\
\hline \multirow{3}{*}{ 1IT08 } & Location & nt & $128-997$ & 1983-1234 & $556-62$ & & 654-1016 & & 1298- 1089 \\
\hline & $\begin{array}{l}\text { Gene length } \\
\text { Protein }\end{array}$ & $\begin{array}{l}\mathrm{nt} \\
\mathrm{aa}\end{array}$ & 870 & 750 & 495 & $\begin{array}{c}\text { Not } \\
\text { detected }\end{array}$ & 363 & $\begin{array}{c}\text { Not } \\
\text { detected }\end{array}$ & 210 \\
\hline & length & $(\mathrm{kDa})$ & $289(33.5)$ & $249(29.3)$ & $164(18.1)$ & & $120(12.9)$ & & $69(7.8)$ \\
\hline \multirow{3}{*}{ 9IT11 } & Location & nt & $128-997$ & $1984-1235$ & $556-62$ & & 654-1016 & & \\
\hline & $\begin{array}{l}\text { Gene length } \\
\text { Protein }\end{array}$ & $\begin{array}{l}\text { nt } \\
\text { aa }\end{array}$ & 870 & 750 & 495 & $\begin{array}{c}\text { Not } \\
\text { detected }\end{array}$ & 363 & $\begin{array}{c}\text { Not } \\
\text { detected }\end{array}$ & $\begin{array}{c}\text { Not } \\
\text { detected }\end{array}$ \\
\hline & length & $(\mathrm{kDa})$ & $289(33.5)$ & $249(29.3)$ & $164(18.1)$ & & $120(12.9)$ & & \\
\hline \multirow[b]{2}{*}{ 10IT11 } & Location & nt & $127-996$ & $1982-1233$ & $555-61$ & & 653-1015 & & 1297- 1088 \\
\hline & $\begin{array}{c}\text { Gene length } \\
\text { Protein } \\
\text { length }\end{array}$ & $\begin{array}{c}\mathrm{nt} \\
\mathrm{aa} \\
(\mathrm{kDa}) \\
\end{array}$ & $\begin{array}{c}870 \\
289(33.5) \\
\end{array}$ & $\begin{array}{c}750 \\
249(29.3) \\
\end{array}$ & $\begin{array}{c}495 \\
164(18.1)\end{array}$ & $\begin{array}{c}\text { Not } \\
\text { detected }\end{array}$ & $\begin{array}{c}363 \\
120(12.9) \\
\end{array}$ & $\begin{array}{c}\text { Not } \\
\text { detected }\end{array}$ & $\begin{array}{c}210 \\
69(7.8) \\
\end{array}$ \\
\hline
\end{tabular}




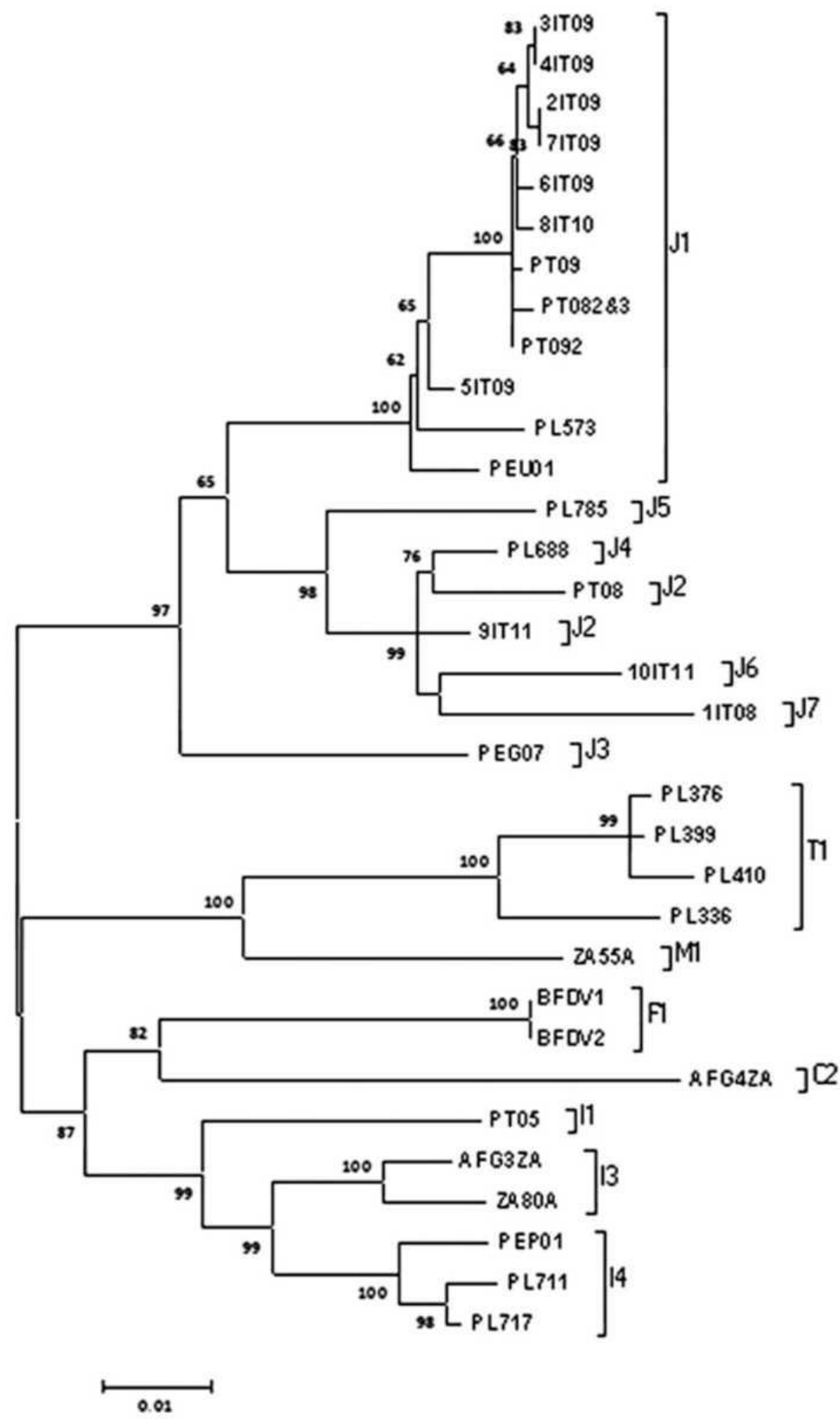

Figure 2. Bayesian phylogenetic tree of the complete nucleotide sequences of BFDV obtained from the African grey parrots: 10 Italian strains and 14 BFDV NCBI reference sequences with strain and subtype demarcation. Posterior probability values are reported below branches. Bar: 0.01 substitutions per site. The phylogeny divided the BFDV into clusters and the sequences analysed in this study are included in group $J$ and subgroups $J 1$ to $J_{7}$. 


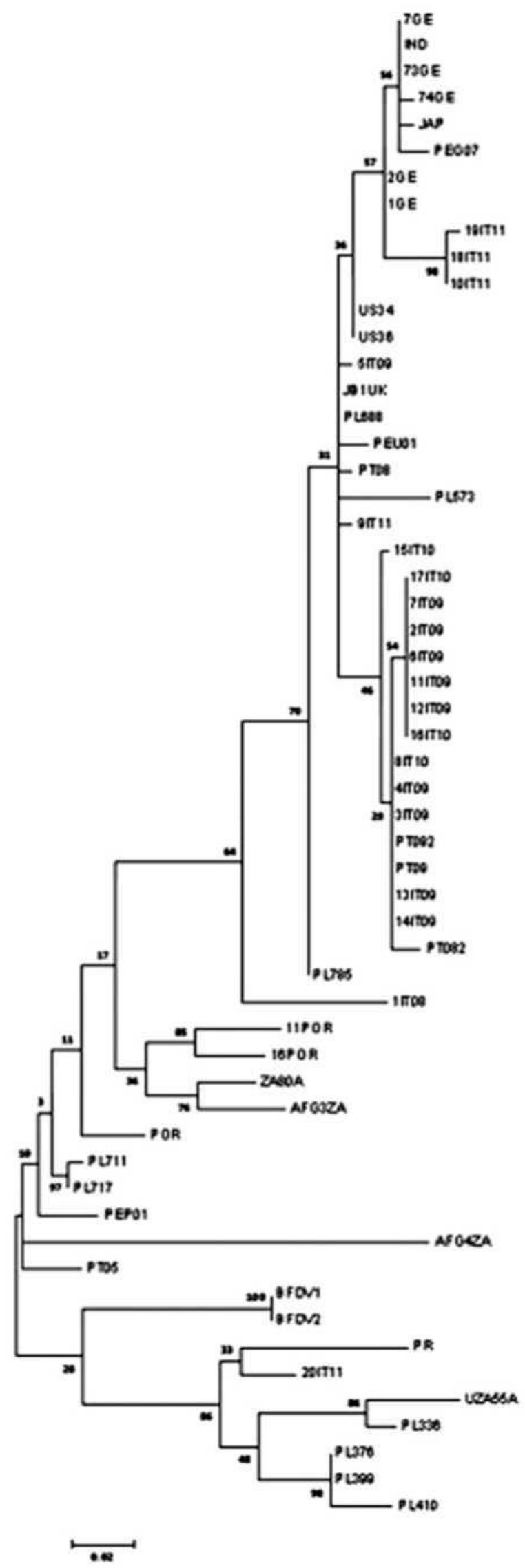

Figure 3. Phylogenetic analysis of 20 deducted amino acid cp sequences ofBFDVs obtained from African grey parrots: 20 Italian strains and 28 BFDV NCBI reference sequences are included in this analysis. The tree showed close correlations between viral strains of birds from the same breeding centres ( $a$ and $b$ ). 


\section{References}

1. Adair, B.M. (1996). Virus induced immunosuppression. In T.F. Davidson, T.R. Morris, \& L.N. Payne (Eds.), Poultry Immunology (pp. 301-315). Abingdon: Carfax.

2. Adair, B.M. (2000). Immunopathogenesis of chicken anemia virus infection. Development and Comparative Immunology, 24, 247-255.

3. Adair, B.M., McNeilly, F., McConnell, C.D.G., Todd, D., Nelson, R.T. \& McNulty, M.S. (1991). Effects of chicken anemia agent on lymphokine production and lymphocyte transformation in experimentally infected chickens. Avian Diseases, 35, $783-792$.

4. Adair, B.M. \& McNulty, M.S. (1997). Lymphocyte transformation and lymphokine production during chicken anemia virus infection. In V.E.C.J. Schijns \& M.C. Horzinek (Eds.), Cytokines in Veterinary Medicine (pp. 301-310). Wallingford: CAB International.

5. Akaike, H. (1973). Information theory and an extension of an extension of the maximum likelihood principle. Proceeding of the 2nd International Symposium on Information Theory (pp. 267-281). Budapest, Hungary.

6. Bassami, M.R., Berryman, D., Wilcox, G.E. \& Raidal, S.R. (1998). Psittacine beak and feather disease virus nucleotide sequence analysis and its relationship to porcine circovirus, plant circoviruses, and chicken anaemia virus. Virology, 249, 453^59.

7. Bassami, M.R., Ypelaar, I., Berryman, D., Wilcox, G.E. \& Raidal, S.R. (2001). Genetic diversity of beak and feather disease virus detected in psittacine species in Australia. Virology, 279, 392^100.

8. Bert, E., Tomassone, L., Peccati, C., Navarrete, M.G. \& Cerruti Sola, S.C. (2005). Detection of beak and feather disease virus (BFDV) and avian polyomavirus (APV) DNA in psittacine birds in Italy. Journal ofVeterinary Medicine. B, Infectious diseases and veterinary public health, 52, 64-68.

9. Bounous, D.I., Goodwin, M.A., Brooks, R.L., Lamichhane, C.M., Cam-pagnoli, R.P., Brown, J. \& Snyder, D.B. (1995). Immunosuppression and intracellular signalling in splenocytes from chicks infected with chicken anemia virus, CL-1 isolate. Avian Diseases, 39, 135-140.

10. Danen-van Oorschot, A.A., van der Eb, A.J. \& Noteborn, M.H. (1999). BCL-2 stimulates apoptin-induced apoptosis. Advances in Experimental Medicine and Biology, 457, 245-249.

11. Danen-van Oorschot, A.A., van der Eb, A.J. \& Noteborn, M.H. (2000). The chicken anemia virus-derived protein apoptin requires activation of caspases for induction of apoptosis in human tumor cells. Journal of Virology, 74, 7072-7028.

12. de Kloet, E. \& de Kloet, S.R. (2004). Analysis of the beak and feather disease viral genome indicates the existence of several genotypes which have a complex psittacine host specificity. Archives of Virology, 149, 2393-2412.

13. Doneley, R.J. (2003). Acute beak and feather disease in juvenile African Grey parrotsan uncommon presentation of a common disease. Australian Veterinary Journal, 8, $206-207$.

14. Etherington, G.J., Dicks, J. \& Roberts, I.N. (2006). High throughput sequence analysis reveals hitherto unreported recombination in the genus Norovirus. Virology, 345, 88-95.

15. Faurez, F., Dory, D., Grasland, B. \& Jestin, A. (2009). Replication of porcine circoviruses. Virology Journal, 6, 60.

16. Gerlach, H. (2004). Circoviridae-psittacine beak and feather disease virus. In B.W. Ritchie, G.J. Harrison, \& L.R. Harrison (Eds.), Avian Medicine: Principles and Application (pp. 894-903). Lake Worth, FL: Wingers.

17. Ghayur, T., Banerjee, S., Hugunin, M., Butler, D., Herzog, L., Carter, A., Quintal, L., Sekut, L., Talanian, R. \& Paskind, M. (1997). Caspase-1 processes IFN-gammainducing factor and regulates LPS-induced IFN-gamma production. Nature, 386, 619623.

18. Goryo, M., Shibata, Y., Suwa, T., Umemura, T. \& Itakura, C. (1987). Outbreak of anaemia associated with chicken anaemia agent in young chicks. Japanese Journal ofVeterinary Science, 49, 867-873.

19. Heath, L., Martin, D.P., Warburton, L., Perrin, M., Horsfield, W., Kingsley, C., Rybicki, 
E.P. \& Williamson, A.L. (2004). Evidence of unique genotypes of beak and feather disease virus in southern Africa. Journal of Virology, 78, 9277-9284.

20. Heath, L., Williamson, A.L. \& Rybicki, E.P. (2006). The capsid protein of beak and feather disease virus binds to the viral DNA and is responsible for transporting the replication-associated protein into the nucleus. Journal of Virology, 80, 7219-7225.

21. Henriques, A. M., Fagulha, T., Duarte, M., Ramos, F., Barros, S., Luis, T., Bernardino, R. \& Fevereiro, M. (2010). Phylogenetic analysis of six isolates of beak and feather disease virus from African grey parrots in Portugal. Avian Diseases, 54, 1066-1071.

22. Huelsenbeck, J.P. \& Ronquist, F. (2001). MRBAYES: Bayesian inference of phylogenetic trees. Bioinformatics, 17, 754-755.

23. Hughes, A.L. \& Piontkivska, H. (2008). Nucleotide sequence polymorphism in circoviruses. Infection, Genetics and Evolution, 8, 130-138.

24. Julian, L., Piasecki, T., Chrzastek, K., Walters, M., Muhire, B., Harkins, G.W., Martin, D.P. \& Varsani, A. (2013). Extensive recombination detected among beak and feather disease virus isolates from breeding facilities in Poland. Journal of General Virology, 79, 94, 1086-1095.

25. Liu, J., Chen, I. \& Kwang, J. (2005). Characterization of a previously unidentified viral protein in porcine circovirus type 2 -infected cells and its role in virus-induced apoptosis. Journal of Virology, 79, 8262-8274.

26. Mankertz, A., Mankertz, J., Wolf, K. \& Buhk, H.J. (1998). Identification of a protein essential for replication of porcine circovirus. Journal of General Virology, 79, 381384.

27. Nei, M. \& Gojobori, T. (1986). Simple methods for estimating the numbers of synonymous and nonsynonymous nucleotide substitutions. Molecular Biology and Evolution, 3, 418^126.

28. Niagro, F.D., Forsthoefel, A.N., Lawther, R.P., Kamalanathan, L., Ritchie, B. W., Latimer, K.S. \& Lukert, P.D. (1998). Beak and feather disease virus and porcine circovirus genomes: intermediates between the geminiviruses and plant circoviruses. Archives of Virology, 143, 1723-1744.

29. Otaki, Y., Tajima, M., Saito, K. \& Nomura, K. (1988). Immune response of chicks inoculated with chicken anemia agent alone on in combination with Marek's disease virus or turkey herpesvirus. Japanese Journal of Veterinary Science, 50, 1040-1047.

30. Pietersen, A. \& Noteborn, H.M. (2000). Apoptin. Advances in Experimental Medicine and Biology, 465, 153-161.

31. Posada, D. \& Crandall, K.A. (1998). MODELTEST: testing the model of DNA substitution. Bioinformatics, 14, 817-818.

32. Posada, D. \& Crandall, K.A. (2001). Selecting the best-fit model of nucleotide substitution. Systematic Biology, 50, 580-601.

33. Rahaus, M., Desloges, N., Probst, S., Loebbert, B., Lantermann, W. \& Wolff, M.H. (2008). Detection of beak and feather disease virus DNA in embryonated eggs of psittacine birds. Veterinarni Medicina, 53, 53-58.

34. Rahaus, M. \& Wolff, M.H. (2003). Psittacine beak and feather disease: a first survey of the distribution of beak and feather disease virus inside the population of captive psittacine birds in Germany. Journal of Veterinary Medicine. B, Infectious diseases and veterinary public health, 50, 368-371.

35. Randall, C.J., Siller, W.G., Wallis, A.S. \& Kirkpatrick, K.S. (1984). Multiple infections in young broilers. The Veterinary Record, 114, 270-271.

36. Raue, R., Johne, R., Crosta, L., Burkle, M., Gerlach, H. \& Muller, H. (2004) Nucleotide sequence analysis of a $\mathrm{C} 1$ gene fragment of psittacine beak and feather disease virus amplified by real-time polymerase chain reaction indicates a possible existence of genotypes. Avian Pathology, 33, 41-50.

37. Ritchie, B.W. (1995). Circoviridae. In B.W. Ritchie (Ed.), Avian Viruses, Function and control (pp. 223-252). Lake Worth, FL: Wingers. Ritchie, P.A., Anderson, I.L. \& Lambert, D.M. (2003). Evidence for specificity of psittacine beak and feather disease viruses among avian hosts. Virology, 306, 109-115.

38. Ritchie, B.W., Niagro, F.D., Lukert, P.D., Steffens, W. L. 3rd. \& Latimer, K.S. (1989). Characterization of a new virus from cockatoos with psittacine beak and feather disease. Virology, 171, 83-88.

39. Ronquist, F. \& Huelsenbeck, J.P. (2003). MrBayes 3: Bayesian phylogen-etic inference under mixed models. Bioinformatics, 19, 1572-1574.

40. Schoemaker, N.J., Dorrestein, G.M., Latimer, K.S., Lumeij, J.T., Kik, M.J., van der 
Hage, M.H. \& Campagnoli, R.P. (2000). Severe leukopenia and liver necrosis in young African grey parrots (Psittacus erithacus erithacus) infected with psittacine circovirus. Avian Diseases, 44, 470^178.

41. Swofford, D. (2003). PAUP*. Phylogenetic Analysis Using Parsimony (*and Other Methods) (Version 4.0). Sunderland, MA: Sinauer Associates.

42. Thompson, J.D., Gibson, T.J., Plewniak, F., Jeanmougin, F. \& Higgins, D. G. (1997). The CLUSTAL_X windows interface: flexible strategies for multiple sequence alignment aided by quality analysis tools. Nucleic Acids Research, 25, 4876^1882.

43. Thornberry, N.A. \& Lazebnik, Y. (1998). Caspases: enemies within. Science, 281, 1312-1316.

44. Todd, D. (2000). Circoviruses: immunosuppressive threats to avian species: a review. Avian Pathology, 29, 373-394.

45. Todd, D., McNulty, M.S., Adair, B.M. \& Allan, G.M. (2001); Animal circoviruses. Advances in Virus Research, 57, 1-70.

46. Varsani, A., Regnard, G.L., Bragg, R., Hitzeroth, II. \& Rybicki, E.P. (2011). Global genetic diversity and geographical and host-species distribution of beak and feather disease virus isolates. Journal of General Virology, 92, 752-767.

47. Ypelaar, I., Bassami, M.R., Wilcox, G.E. \& Raidal, S.R. (1999). A universal polymerase chain reaction for the detection of psittacine beak and feather disease virus. Veterinary Microbiology, 68, 141-148.

48. Zhuang, S.M., Landegent, J.E., Verschueren, C.A., Falkenburg, J.H., van Ormondt, H., van der Eb, A.J. \& Noteborn, M.H. (1995a). Apoptin, a protein encoded by chicken anemia virus, induces cell death in various human hematologic malignant cells in vitro. Leukemia Supplements, 1, S118-S120.

49. Zhuang, S.M., Shvarts, A., van Ormondt, H., Jochemsen, A.G., van der Eb, A.J. \& Noteborn, M.H. (1995b). Apoptin, a protein derived from chicken anemia virus, induces p53-independent apoptosis in human osteosarcoma cells. Cancer Research, 55, $486^{\wedge} 189$. 